Бурлака О. А., кандидат технічних наук,

Яхін С. В., кандидат технічних наук,

Дудник В. В., кандидат технічних наук

Полтавська державна аграрна академія

\title{
ЕКСПЕРИМЕНТАЛЬНІ ДОСЛІДЖЕННЯ ПРОЦЕСУ ТРАНСПОРТУВАННЯ ЗЕРНА ЕЛЕВАТОРОМ ЗЕРНОЗБИРАЛЬНОГО КОМБАЙНУ
}

\section{Рецензент - доктор технічних наук В. О. Сукманов}

Мета статmі. Метою иьього дослідження є обтрунтування способу контролю параметрів проходження зернового потоку різних сільськогосподарських культур у скребковому елеваторі зернозбирального комбайна за допомогою удосконаленого нами датчика ємнісно-хвильового типу.

Методика досліджень. Первинні дані експериментальних досліджень, ще були одержані за допомогою спеціально розробленої установки, оброблені за допомогою методів математичного та статистичного аналізу.

Результати досліджень. Якість транспортування зерна скребковими елеваторами, що використовуються на зернозбиральних комбайнах та у транспортних лініях зернопереробних підприємств, не відповідає сучасним вимогам - спостерігається неповнота розвантаження, подрібнення частини зерна скребками, ланцюгом та зірочками елеватора, не враховуються умови роботи транспортної зернової системи комбайна при обмолоті маловрожайних культур зі значною перевагою у врожсаї незернової частини. При дослідженні особливості руху зерна, що транспортується і розвантажується скребковим елеватором, нами була вдосконалена та використана експериментальна установ$\kappa a$, що дообладнана системою контролю інтенсивності транспортування. При проведенні частини експериментальних досліджень вивчалися відображення інтенсивності потоку Y та його залежність від продуктивності елеватора $X_{1}$ і швидкості транспортування $X_{2}$. Для описування залежності $Y$ від $X_{1}$ та $X_{2}$ для кожного виду сільськогосподарських культур використовувалася множинна лінійна регресія. За результатами експериментів інтенсивність зернового потоку можливо розглядати як ступінь завантаження скребкового елеватора відносно номінального значення. У транспортних системах зернопереробних машин така інтенсивність майже завжди номінальна, а на зернозбиральних комбайнах спостерігається часткове неповне завантаження за рахунок різнопланових умов збирання врожаю.

Елементи наукової новизни. Спроектована, виготовлена та використана в наших дослідженнях експериментальна установка, як об'єкт інтелектуальної власності, захищена патентами на винахід та патентами на корисну модель. Також має патентний захист спосіб дослідження технологічних процесів транспортування зерна елеватором. Останнє підтверджує наукову новизну цієї публікації.

Практична значущість. Результати дослідження використані при удосконаленні зернотранспортної лінї̈ зернозбирального комбайна КЗС-9-1 «Славутич» та є вагомими для подальшої оптимізачії режимів транспортування зерна подібними скребковими елеваторами.

Ключові слова: елеватор, зерновий потік, сектор розвантаження, зворотній сип (колова ичикуляція).

Бурлака Олексій Анатолійович - кандидат технічних наук, доцент, доцент кафедри технології та засобів механізації аграрного виробництва, Полтавська державна аграрна академія, вул. Сковороди, 1/3, м. Полтава, 36003, Україна, e-mail: oleksii.burlaka@pdaa.edu.ua, ORCID ID: 0000-0002-22967234.

Яхін Сергій Валерійович - кандидат технічних наук, доцент, завідувач кафедри галузевого машинобудування, Полтавська державна аграрна академія, вул. Сковороди, 1/3, м. Полтава, 36003, Україна, e-mail: sergii.iakhin@pdaa.edu.ua, ORCID ID: 0000-0002-0042-0844.

Дудник Володимир Васильович - кандидат технічних наук, доцент кафедри безпеки життєдіяльності, Полтавська державна аграрна академія, вул. Сковороди, 1/3, м. Полтава, 36003, Україна, e-mail: volodymyr.dudnyk@pdaa.edu.ua, ORCID ID: 0000-0002-6553-2951. 


\section{TEХНIЧНI НАУКИ}

Постановка проблеми. Зерно у світі вважається досить важливим продуктом, а Україна одна із найбільших його експортерів. Вимоги до якості зерна, що збирають у нашій країні, поступово зростають. При цьому, якість транспортування зерна скребковими елеваторами, що використовуються на сучасних зернозбиральних комбайнах та в транспортних лініях зернопереробних підприємств, не повністю відповідає сучасним вимогам: спостерігається неповнота розвантаження, подрібнення частини зерна скребками, ланцюгом та зірочками елеватора [6], не враховуються умови роботи транспортної зернової системи комбайна при обмолоті маловрожайних культур зі значною перевагою у врожаї незернової частини.

Аналіз основних досліджень і публікацій, у яких започатковане розв'язання цісї проблеми. Проблемам теорії та практики, щодо удосконалення транспортних систем сільськогосподарських машин присвятили частину своїх досліджень низка вітчизняних та закордонних учених: Погорілий Л. В. [10], Сакун В. А., Листопад Г. Е., Босой Е. С. та ін. Приділяється велика увага системам точного землеробства в розрізі оцінки врожайності для аналізу необхідності внесення добрив на різних ділянках.

Основними відомими датчиками для вимірювання технологічних характеристик зернових потоків у зерно-транспортних лініях сучасних зернозбиральних комбайнів $є$ датчики намолоту зерна ударного типу, оптичного типу, вагові датчики, радіоактивні датчики $[8,9,10]$. Але одними 3 основних невирішених повністю питань щодо використання систем контролю якості транспортування зерна скребковими елеваторами на основі пропонованих датчиків намолоту зерна є відносна висока вартість такого обладнання, постійна потреба у калібруванні датчиків залежно від мінливих умов збирання врожаю та несумісність систем моніторингу врожайності полів різних виробників сільськогосподарської техніки.

Тому питання підвищення якості транспортування зерна скребковими елеваторами потребують подальшого вдосконалення [7], отже на них i зосереджено головну увагу цього дослідження.

Метою даного дослідження $є$ обгрунтування способу контролю параметрів проходження зернового потоку різних сільськогосподарських культур у скребковому елеваторі зернозбираль- ного комбайна за допомогою удосконаленого нами датчика ємнісно-хвильового типу.

Завдання досліджень. Для досягнення поставленої мети за результатами експериментів із використанням розробленої установки необхідно:

- обгрунтувати оптимальні параметри транспортування зерна для різних сільськогосподарських культур, критерій оптимізації - швидкість транспортування;

- розробити рекомендації щодо зменшення пошкодження зерна під час транспортування та відцентрового розвантаження скребковим елеватором.

Матеріали і методи досліджень. При проведенні даних досліджень використані методи математичного та статистичного аналізу, на основі результатів експериментальних досліджень, що проведені на спеціально розробленій експериментальній установці, яка відтворює роботу зернового елеватора.

Результати досліджень. При дослідженні особливостей руху зерна, що транспортується і розвантажується скребковим елеватором, була використана експериментальна установка $[1,2,3]$.

Схема установки представлена на рис. 1. Об'єкт досліджень - скребковий елеватор 1, який встановлено на рамі 2 під кутом $75^{\circ}$ відносно горизонту, та який має збільшений до $140^{\circ}$ сектор відцентрового розвантаження.

Зерновий потік у зоні завантаження 10 за допомогою транспортної магістралі 8 здійснює рух по колу. Бункер 7 обладнано регулятором продуктивності транспортування 6. Рух елеватора здійснюється за допомогою електричного двигуна 3 через пасову передачу 12. Двигун 3 - машина постійного струму, що дає можливість змінювати швидкість транспортування зерна елеватором у широкому діапазоні. Електричне живлення та регулювання обертів двигуна 3 здійснюється від силової шафи 5 через трансформатор 4. Геометричні параметри зони розвантаження елеватора змінюються за допомогою заслінки 14 . Отвір 13 та ємність 11 використовуються для визначення маси зерна, що здійснює колову циркуляцію в елеваторі 1 . Шків 9 використовується як стабілізатор пасової передачі 12. Схема проходження зернового потоку в зоні розвантаження (зона А рис. 1) більш детально подано на рисунку 2. 


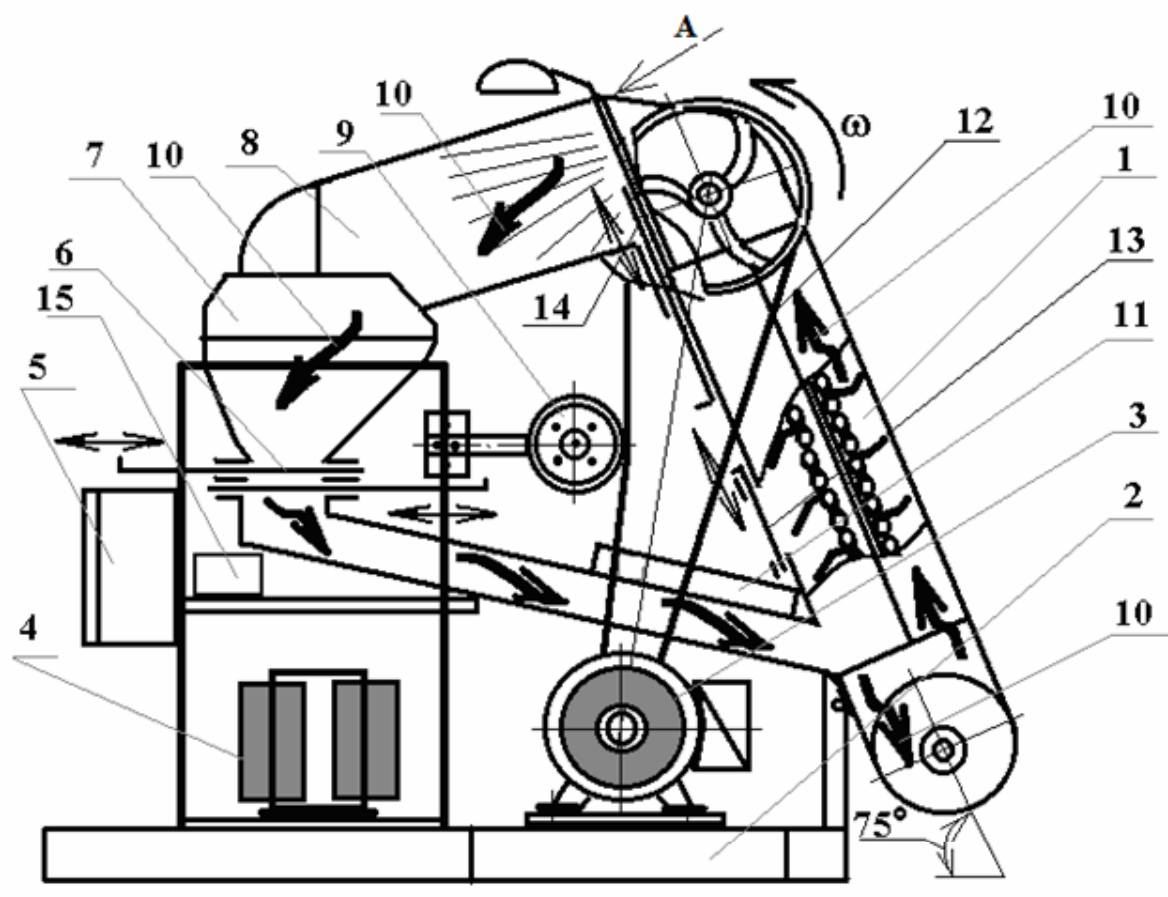

Рис. 1. Схема експериментальної установки

1 - скребковий елеватор; 2 - рама; 3 - електродвигун постійного струму; 4 - трансформатор; 5 - шафа керування електродвигуном; 6 - регулятор продуктивності транспортування; 7 - бункер; 8 - перевантажувальна камера; 9 - натяжний шків; 10 - зона завантаження елеватора та напрям зернового потоку; 11 - ємність для вимірювання частини зворотного сипу зерна (колової циркуляції); 12 - пасова передача; 13 - нижня шиберна заслінка; 14 - верхня шиберна заслінка; 15 - вихідний комп’ютерний блок інтенсивності потоку.

Джерело: удосконалено авторами як продовження авторських досліджень з [1, 2, 3, 4].

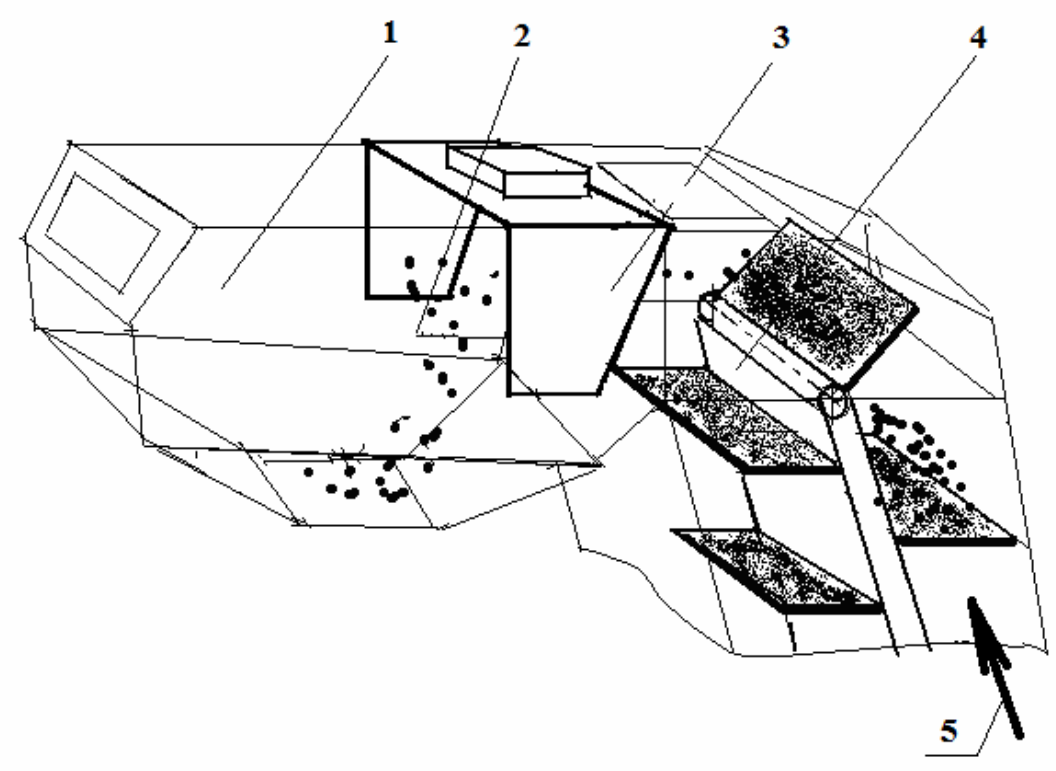

Рис. 2. Схема проходження зернового потоку в зоні розвантаження (зона А (рис. 1))

1 -перевантажувальна камера; зерновий потік; 3 -датчик намолоту зерна; 4-скребковий елеватор; 5 - напрямок потоку зерна (елементи кожухів умовно показані прозорими).

Джерело: авторські дослідження. 


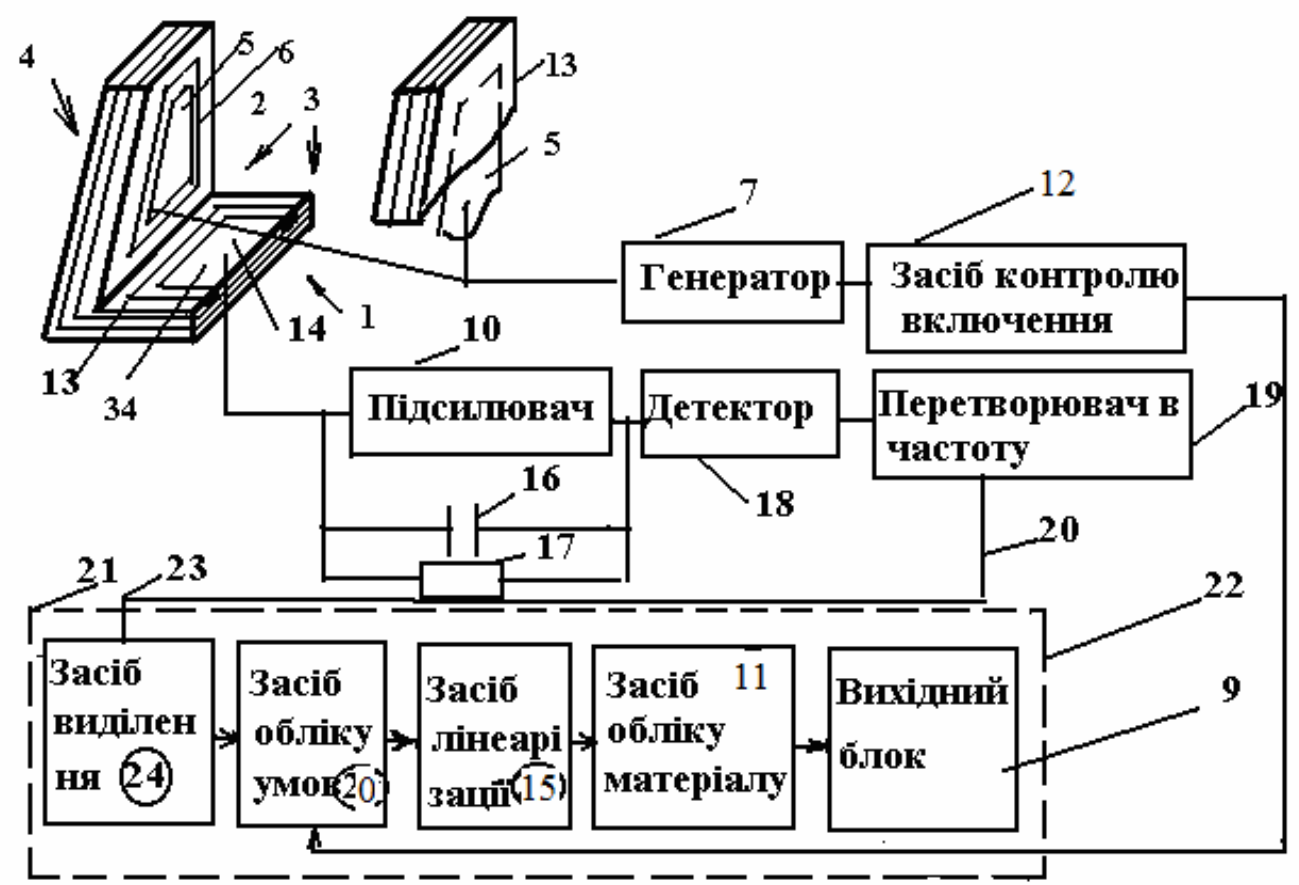

Рис. 3. Функціональна схема пристрою для контролю кількісних характеристик зернових потоків

1 - основа датчика; 2,3 - напрям, що формує зону контролю, 4 -бокова частина датчика, 5 - електроди, 6 - ізолятор, 7 - генератор; 8- електронний блок датчика; 9 - вхідний блок; 10 - підсилювач; 11 - засіб обліку матеріалу; 12 - засіб контролю включення; 13 - екран; 14 - електрод; 15 - засіб лінеаризації; 16 - конденсатор, 17 - резистор; 18 - детектор; 19 - перетворювач у частоту; 20 - засіб обліку умов.

Джерело: [5], удосконалене авторами.

Характерною особливістю такої конструкції $\mathrm{\epsilon}$ встановлення в перевантажувальній камері датчику намолоту зерна 3. Таке технічне рішення дало змогу контролювати інтенсивність зернових потоків сільськогосподарських культур.

Датчик намолоту зерна розглядається як основна частина пристрою для контролю потоків сільськогосподарських матеріалів [5]. Функціональна схема останнього подана на рис. 3 . Пристрій складається щонайменше 3 одного датчика ємнісного типу та комп'ютера для обробки вихідного сигналу з датчика.

Високочастотний датчик має три електроди 14 (з метою утворення зони контролю), генератор електромагнітних коливань 7, 3 виходом якого пов'язаний перший згаданий електрод, засіб екранування зони контролю 13 , підсилювач 103 мережею зворотного від'ємного зв'язку, вхід якого пов'язаний з другим вищезгаданим електродом, детектор 18, вхід якого ввімкнений до виходу підсилювача 10 , а також вихідний блок формування сигналів 9.

Електроди виконані як відкриті струмопровідні поверхні, ізольовані від засобів екра- нування зони контролю по торцях та збоку, протилежного зоні контролю, діелектричними прокладками. Таке виконання датчика підвищує його технологічні можливості при використанні його для контролю абразивних потоків сільськогосподарських матеріалів, бо зменшується вплив зносу на надійність контролю.

При проведенні експериментальних досліджень вихідним параметром було встановлено відображення інтенсивності потоку $Y$ пристроєм для контролю потоків сільськогосподарських матеріалів.

Експериментально вивчено відображення інтенсивності потоку $Y$ та його залежність від продуктивності елеватора $X_{1}$ і швидкості транспортування $X_{2}$. Для описування залежності $Y$ від $X_{I}$ та $X_{2}$ для кожного виду сільськогосподарських культур використовувалася множинна лінійна регресія:

$$
Y_{i}=\beta_{0}+\beta_{1} X_{1}+\beta_{2} X_{2},
$$

де $\beta_{0} ; \beta_{1} ; \beta_{2}-$ коефіцієнти регресії. 
Експериментальні дослідження було проведено при $3 . . .4$ повторюваннях із зерном різних сільськогосподарських культур, а саме: озима пшениця, соя, ячмінь, люцерна, горох.

Розглянемо основні результати регресійного аналізу [4] для озимої пшениці. Оцінки коефіцієнтів регресії $\beta_{0}=1009,63 ; \beta_{1}=9,81 ; \beta_{1}=-2,69$. Отже, оцінка рівняння множинної регресії $є$ :

$$
Y=1009,63+9,81 X_{1}-2,69 X_{2} .
$$

Оцінка дисперсії помилки є $M S_{R}=15,97$, а стандартна помилка оцінки $s=\sqrt{15,97}=3,997$. Нарешті, відношення $R^{2}=S S_{D} / S S_{T}=5000,97 / 5560,095==0,899$ є долею дисперсії, що пояснена регресією $Y$ по $X_{1}, X_{2}$.

Результати регресійного аналізу для сої відповідно: оцінки коефіцієнтів регресії $\beta_{0}=-155,02$; $\beta_{1}=8,794 ; \beta_{1}=0,442$ оцінка рівняння множинної регресії:

$$
Y=-155,2+8,974 X_{1}-0,442 X_{2} .
$$

Оцінка дисперсії помилки є $M S_{R}=7,85$, а стандартна помилка оцінки $S=\sqrt{7,85}=2,8$. Відношення $R^{2}=S S_{D} / S S_{T}=10661,82 / 11077,83=0,96$ є долею дисперсії, що пояснена регресією $Y$ по $X_{1}, X_{2}$.

Для ячменю одержані такі значення коефіціснтів: $\beta_{0}=315,97 ; \beta_{1}=9,109 ; \beta_{1}=-0,87$;

$$
Y=315,97+9,109 X_{1}-0,87 X_{2} \text {, }
$$

$M S_{R}=7,85 ; s=\sqrt{3,92}=1,98 ; R^{2}=S S_{D} / S S_{T}=2821,88 / 2959,08=0,95$ - доля дисперсії, що пояснена регресією $Y$ по $X_{1}, X_{2}$.

Для люцерни було одержано: $\beta_{0}=50,15 ; \beta_{1}=90,495 ; \beta_{1}=-0,13$.

$$
Y=50,15+90,495 X_{1}-0,13 X_{2},
$$

$$
M S_{R}=2,67 ; s=\sqrt{2,67}=1,634 ; R^{2}=S S_{D} / S S_{T}=837,61 / 896,36=0,934 \text { - доля дис- }
$$
персії, що пояснена регресією $Y$ по $X_{1}, X_{2}$.

І останнє, для гороху: $\beta_{0}=315,97 ; \beta_{1}=9,109 ; \beta_{1}=-0,32$;

$$
Y=315,97+9,109 X_{1}-0,32 X_{2},
$$

$M S_{R}=2,84 ; s=\sqrt{2,84}=1,685 ; R^{2}=S S_{D} / S S_{T}=2394,88 / 2465,86=0,97$ - доля дисперсії, що пояснена регресією $Y$ по $X_{1}, X_{2}$.

3 метою визначення вагомості впливу на відображення потоку виду сільськогосподарських культур проводимо вибір експериментальних даних за умови фіксованої швидкості транспортування. Маловпливові фактори, що були визначені раніше (засміченість та вологість зерна), при цьому не враховуємо.

За одержаними даними обчислені залежності відображення потоку від витрат зерна для кожного виду сільськогосподарських культур. Результати розрахунків наочно засвідчують графіки, що подані на рис. 4.

При встановленні фіксованої швидкості транспортування на рівні 350 об/хв., що відповідає швидкості веденого шківа елеватора, математичні моделі відображення потоку залежно від витрат зерна запишуться у вигляді:

- пшениця $-Y=45,93+13,68 X_{1}$;

- соя $-Y=4,06+7,50 X_{1}$;

- ячмінь $-Y=9,65+8,42 X_{1}$;

- люцерна $-Y=4,95+72,9 X_{1}$;

- горох $-Y=9,34+6,59 X_{1}$. 


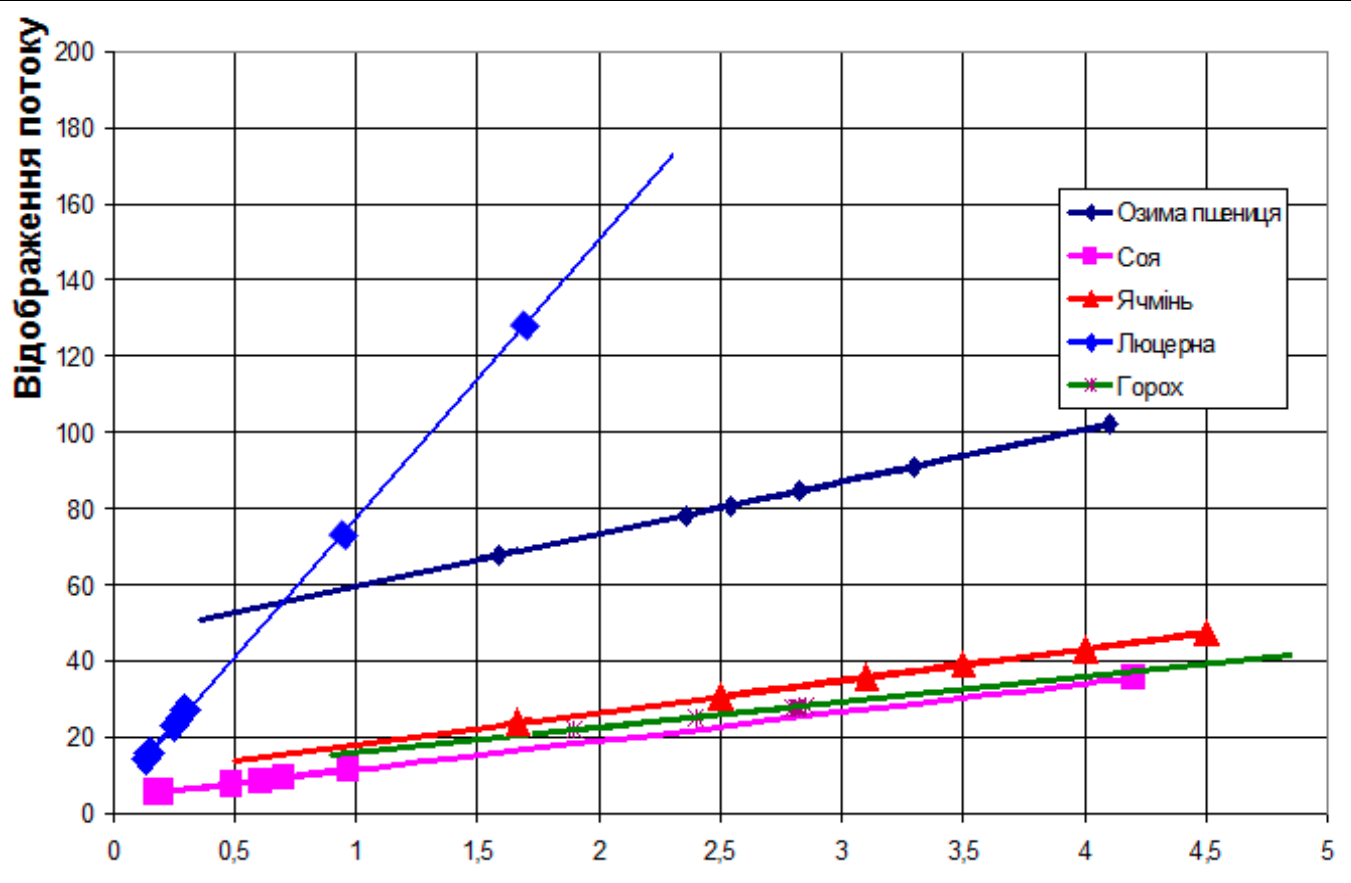

Продуктивність елеватора, кг/с

\section{Рис. 4. Графіки залежності відображення потоку від продуктивності елеватора при фіксованій швидкості транспортування 350 об/хв.}

Джерело: авторські дослідження.

Аналіз експериментальних залежностей (рис. 4) засвідчує, що регресійні криві суттєво відрізняються для таких сільськогосподарських культур, як пшениця, люцерна, порівняно між собою та з горохом, соєю і ячменем. Тобто при складанні алгоритму визначення кількісних характеристик зернових потоків у комбайні необхідно окремо враховувати тип сільськогосподарських культур.

Висновки 3 даного дослідження і перспективи подалыших розвідок у даному напрямі:

1. Якість транспортування зерна скребковими елеваторами, що використовуються на зернозбиральних комбайнах та в транспортних лініях зернопереробних підприємств, не відповідає сучасним вимогам: спостерігається неповнота розвантаження, подрібнення частини зерна скребками, ланцюгом та зірочками елеватора, не враховуються умови роботи транспортної зернової системи комбайна при обмолоті маловрожайних культур зі значною перевагою у врожаї незернової частини.

2. При дослідженні особливості руху зерна, що транспортується і розвантажується скребковим елеватором, нами була спроектована та виготовлена експериментальна установка. За допомогою останньої було заплановано низку експериментальних досліджень, при проведенні яких стало питання вимірювання інтенсивності зернового потоку, що транспортує та розвантажує скребковий елеватор.
3. Пристрій для вимірювання та контролю інтенсивності зернового потоку складається 3 оригінального датчика намолоту зерна ємнісно-хвильового типу та спеціального комп'ютера, що виконує функцію обробки первинного сигналу з датчика.

4. При проведенні частини експериментальних досліджень вивчалися відображення інтенсивності потоку $Y$ та його залежність від продуктивності елеватора $X_{1}$ і швидкості транспортування $X_{2}$. Для описування залежності $Y$ від $X_{1}$ та $X_{2}$ для кожного виду сільськогосподарських культур використовувалася множинна лінійна регресія.

5. Виявлено, що регресійні моделі, які описують залежності $Y$ від $X_{1}$ та $X_{2}$, суттєво відрізняються для таких сільськогосподарських культур, як пшениця, люцерна, порівняно між собою та 3 горохом, соєю і ячменем. Тобто, при складанні алгоритму визначення кількісних характеристик зернових потоків у елеваторі необхідно окремо враховувати тип сільськогосподарських культур.

6. Інтенсивність зернового потоку можливо розглядати як ступінь завантаження скребкового елеватора відносно номінального значення, i, якщо у транспортних системах зернопереробних машин така інтенсивність майже завжди номінальна, то на зернозбиральних комбайнах спостерігається часткове неповне завантаження за рахунок різнопланових умов збирання врожаю. 


\section{ТЕХНІЧНІ НАУКИ}

7. Одержані результати експериментальних досліджень у подальшому будуть використані для

\section{БІБЛІОГРАФІЯ:}

1. Установка для дослідження технологічних процесів елеватора комбайна: Пат. 41504 Україна : МПК (2009) A01D 41/00 № u 200814677 ; заявлений 22.12.2008; опубл. 25.05.2009, Бюл. №10.

2. Спосіб дослідження технологічних процесів Пат. 41557, Україна: МПК (2009) A01D 41/00 № u $2008 \quad 15248$; заявлений 29.12.2008 ; опубл.25.05.2009, Бюл. №10.

3. Установка для дослідження технологічних процесів елеватора комбайна Пат. 91783 Україна: МПК(2009) A01D 61/00, A01D 93/00 №: а 2009 01515; дата подання заявл. 23.02.2009 ; опубл. 25.08.2010, Бюл. №16.

4. Бурлака О. А. Дослідження технологічного процесу розвантаження та обгрунтування параметрів підйомного елеватора зернозбирального комбайна : дис. канд. техн. наук: 05.20.01. Київ, 2000. 239 c.

5.Пристрій для контролю відносного переміщення рослинного матеріалу Пат. 1389 Україна МПК А 01 В 69/04 00 №: а 1992 01109; дата подання заявл. 23.11.92; Опубл. 25.03.94. Бюл. №1 .

\section{REFERENCES}

1. Ustanovka dlia doslidzhennia tekhnolohichnykh protsesiv elevatora kombaina: Pat. 41504 Ukraina [Installation for research of technological processes of elevator combine: Pat. 41504 Ukraine]: MPK (2009) A01D 41/00 \# u 2008 14677; Biul. № 10 [In Ukrainian].

2. Sposib doslidzhennia tekhnolohichnykh protsesiv Pat. 41557, Ukraina [Method of study of technological processes Pat. 41557, Ukraine] : MPK (2009) A01D 41/00 \# u 200815248 ; Biul. № 10 [In Ukrainian].

3. Ustanovka dlia doslidzhennia tekhnolohichnykh protsesiv elevatora kombaina Pat. 91783 Ukraina [Installation for research of technological processes elevator of harvester Pat. 91783 Ukraine]: MPK(2009) A01D 61/00, A01D 93/00 \# a 2009 01515; Biul. № 16 [In Ukrainian].

4. Burlaka, O. A. (2000) Doslidzhennia tekhnolohichnoho protsesu rozvantazhennia ta obgruntuvannia parametriv pidiomnoho elevatora zernozbyralnoho kombaina [Investigation of the technological process of unloading and justification of the parameters of the lifting elevator of the combine harvester]: Candidate's thesis. Kyiv [In Ukrainian]. енергетичної оптимізації процесу транспортування зерна скребковими елеваторами.

6. Бурлака О. А., Яхін С. В. Теоретичні аспекти процесу відцентрового розвантаження зерна у елеваторі зернозбирального комбайну. Вісник Полтавської державної академї. 2017. № 1-2 (84-85). C. 139-143.

7.Бурлака О. А., Яхін С. В. Підвищення ефективності роботи скребкових елеваторів 3 відцентровим типом розвантаження. Вісник Полтавської державної аграрної академї. 2018. № 4. C. 195-200.

8. Герасименко Р. Д., Бровареиь О. О. Система моніторингу врожайності сільськогосподарських культур. Хранение и переработка зерна. 2014. № 7 (184). С.22-25.

9. Куцеенк М. Датчики в системах картування врожайності. The Ukrainian Farmer. 2009. № 910. URL: http://agroit.com.ua/story/46-datchiki-vsistemah-kartirovaniya-urozhaynosti.html (дата звернення: 17.12.2018).

10. Погорілий Л., Івасюк В., Соломаха О. До практичної реалізації моніторингу грунтів у системі точного землеробства. Техніка АПК. 2002. № 10-11 (жовтень-листопад). С. 8-9.

5.Prystrii dlia kontroliu vidnosnoho peremishchennia roslynnoho materialu Pat. 1389 Ukraina [Device for controlling the relative movement of plant material Pat. 1389 Ukraine] : MPK A 01 V 69/04 00 \#: a 1992 01109; Biul. №1 [In Ukrainian].

6. Burlaka, O. A. \& Yakhin, S. V. (2017) Teoretychni aspekty protsesu vidtsentrovoho rozvantazhennia zerna u elevatori zernozbyralnoho kombainu [Theoretical aspects of the process of centrifugal unloading of grain in a grain mill combine harvester]. Visnyk Poltavskoi derzhavnoi akademii, 1-2 (84-85), pp. 139-143 [In Ukrainian].

7. Burlaka, O. A. \& Yakhin, S. V. (2018). Pidvyshchennia efektyvnosti roboty skrebkovykh elevatoriv $\mathrm{z}$ vidtsentrovym typom rozvantazhennia [Increase the efficiency of scraper elevators with a centrifugal type of discharge]. Visnyk Poltavskoi derzhavnoi ahrarnoi akademii, 4, pp. 195-200 [In Ukrainian].

8. Herasymenko, R. D., Brovarets, O. O. (2014). Systema monitorynhu vrozhainosti silskohospodarskykh kultur. Khranenye y pererabotka zerna. [Crop yield monitoring system] 


\section{ТЕХНІЧНІ НАУКИ}

Khranenye y pererabotka zerna, 7, pp. 22-25

[In Ukrainian].

9. Kutsenko, M. (2009). Datchiki v sistemah kartuvannya vrozhaynosti. [Sensors in the systems of mapping yields]. The Ukrainian Farmer, 9-10. Retrieved from: http://agroit.com.ua/story/46-datchiki$\mathrm{v}$-sistemah-kartirovaniya-urozhaynosti.html
[In Ukrainian].

10. Pohorilyi, L., Ivasiuk, V., Solomakha, O. (2002). Do praktychnoi realizatsii monitorynhu gruntiv u systemi tochnoho zemlerobstva [To practical implementation of soil monitoring in the system of precision farming] Tekhnika APK 10-11, pp. 8-9 [In Ukrainian].

Бурлака А. А., Яхин С. В., Дудник В. В. Экспериментальные исследования процесса транспортировки зерна элеватором зерноуборочного комбайна

Цель статьи. Целью данного исследования является обоснование способа контроля параметров прохождения зернового потока различных сельскохозяйственных культур в скребковом элеваторе зерноуборочного комбайна с помощью усовершенствованного нами датчика емкостно-волнового типа.

Методика исследований. Первичные данные экспериментальных исследований, полученные с помощью специально разработанной установки, обработаны с помощью методов математического и статистического анализа.

Результаты исследований. Качество транспортировки зерна скребковыми элеваторами, используемые на зерноуборочных комбайнах и в транспортных линиях зерноперерабатываюших предприятий, не соответствует современным требованиям - наблюдается неполнота разгрузки, дробление зерна скребками, иепью и звездочками элеватора, не учитываются условия работы транспортной зерновой системы комбайна при обмолоте малоурожайных культур со значительным преимуществом в урожае незерновой части. При исследовании особенности движения зерна при транспортировании и разгрузки скребковым элеватором, нами была усовершенствована и использована экспериментальная установка, дооборудованная системой контроля интенсивности транспортировки. При проведении экспериментальных исследований изучалось отображения интенсивности потока в зависимости от производительности элеватора и скорости транспортировки. Для описания зависимости отображение интенсивности потока для каждого вида сельскохозяйственных культур использовалась множественная линейная регрессия. По результатам экспериментов интенсивность зернового потока можно рассматривать как степень загрузки скребкового элеватора относительно номинального значения. В транспортных системах зерноперерабатывающих машин такая интенсивность почти всегда номинальная, а на зерноуборочных комбайнах наблюдается частичная неполная загрузка за счет разноплановых условий сбора урожсая.

Элементы научной новизны. Усовершенствована и использована в наших исследованиях экспериментальная установка как объект интеллектуальной собственности защищена патентами на изобретение и патентами на полезную модель. Также патентную защиту имеет способ исследования технологических прочессов транспортировки зерна элеватором. Последнее подтверждает научную новизну данной публикачии.

Практическая значимость. Результаты исследования использованы при совершенствовании зернотранспортной линии зерноуборочного комбайна КЗС-9-1 «Славутич» и являются весомыли для дальнейтей оптимизачии режимов транспортировки зерна аналогичныли скребковыми элеваторами.

Ключевые слова: элеватор, зерновой поток, сектор разгрузки, обратная сыпь (круговая циркулячия).

Бурлака Алексей Анатольевич - кандидат технических наук, доцент, доцент кафедры технологии и средств механизации аграрного производства, Полтавская государственная аграрная академия, ул. Сковороды, 1/3, г. Полтава, 36003, Украина, e-mail: oleksii.burlaka@pdaa.edu.ua, ORCID ID: 00000002-2296-7234.

Яхин Сергей Валериевич - кандидат технических наук, доцент, заведующий кафедры отраслевого машиностроения, Полтавская государственная аграрная академия, ул. Сковороды, 1/3, г. Полтава, 36003, Украина, e-mail: sergii.iakhin@pdaa.edu.ua, ORCID ID: 0000-0002-0042-0844.

Дудник Владимир Васильевич - кандидат технических наук, доцент кафедры безопасности жизнедеятельности, Полтавская государственная аграрная академия, ул. Сковороды, 1/3, г. Полтава, 36003, Украина, e-mail: volodymyr.dudnyk@pdaa.edu.ua, ORCID ID: 0000-0002-6553-2951. 


\section{TEХНІЧНІ НАУКИ}

Burlaka $A$. A., Yakhin S. V., Dudnyk $V . V$. Experimental studies of the process of grain transportation by the elevator of grain combine harvester

The purpose of this study is to substantiate the method of monitoring the parameters of grain stream flow of various crops in the scraper elevator of a grain combine harvester using an improved capacitivewave type sensor.

Methods of the research. The primary data of experimental studies, obtained with the help of a specially developed device, have been processed using mathematical and statistical analysis methods.

The research results. The quality of grain transportation by scraper elevators used on combine harvesters and in transportation lines of grain processing enterprises does not meet modern requirements - there is incomplete unloading, grain crushing by scrapers, chain and sprockets of the elevator. The operating conditions of the combine grain transportation system while threshing low-yield crops with a significant advantage of non-cereal part in the yield were not taken into account. Studying the characteristics of grain flow during transportation and unloading by the scraper elevator, we have improved and used the experimental installation, which was additionally equipped with a system for monitoring the intensity of transportation. In the course of experimental studies, the reflection of the flow intensity was studied depending on the elevator production performance and transportation speed. We used multiple linear regression to describe the dependence of reflecting the intensity of the flow for each type of crop. According to the results of the experiments, the intensity of the grain flow can be considered as the degree of loading the scraper elevator relative to the nominal value. In the transport systems of grain processing machines, such intensity is almost always nominal, and on grain combine harvesters there is a partial incomplete loading due to diverse harvesting conditions.

The elements of scientific novelty. The experimental installation has been improved and used in our research as an object of intellectual property, protected by patents for invention and patents for a useful model. The method of studying technological processes of grain transportation by elevator also has patent protection. The latter one confirms the scientific novelty of this publication.

Practical importance. The results of the research have been used to improve the grain transportation line of the KZS-9-1 "Slavutych" combine harvester and they are significant for further optimization of grain transportation modes with similar scraper elevators.

Key words: elevator, grain flow, sector of unloading, return fall (circular circulation).

Burlaka Oleksiy Anatoliiovych - Candidate (PhD) of Technical Sciences, Associate Professor of the Department of Technology and Means for Mechanization of Agrarian Production, Poltava State Agrarian Academy, 1/3, Skovorody st., Poltava, 36003, Ukraine, e-mail: oleksii.burlaka@pdaa.edu.ua, ORCID ID: 0000-0002-2296-7234.

Yakhin Sergii Valeriiovych - Candidate $(\mathrm{PhD})$ of Technical Sciences, Associate Professor, Head of the Department of Branch Machine Building, Poltava State Agrarian Academy, 1/3, Skovorody st., Poltava, 36003, Ukraine, e-mail: sergii.iakhin@pdaa.edu.ua, ORCID ID: 0000-0002-0042-0844.

Dudnyk Volodymyr Vasyliovych - Candidate (PhD) of Technical Sciences, Associate Professor of the Department of Life Safety, Poltava State Agrarian Academy, 1/3, Skovorody st., Poltava, 36003, Ukraine, e-mail: volodymyr.dudnyk@pdaa.edu.ua, ORCID ID: 0000-0002-6553-2951.

Стаття надійшла до редакції 20.02.2019 р.

\section{Бібліографічний опис для цитування :}

Бурлака О. А., Яхін С. В., Дудник В. В. Експериментальні дослідження процесу транспортування зерна елеватором зернозбирального комбайну. Вісник ПДАА. 2019. № 1. С. 232-240.

DOI 10.31210/visnyk2019.01.28

(C) Бурлака Олексій Анатолійович, Яхін Сергій Валерійович, Дудник Володимир Васильович, 2019 